\title{
Avgift som motgift
}

Dei fleste som døyr av tobakksbruk, bur i land der sigarettane kostar omtrent like mykje som ei pakke tyggegummi. I mange land kan ei avgiftsauke gje enorm gevinst - i liv, helse og kroner.

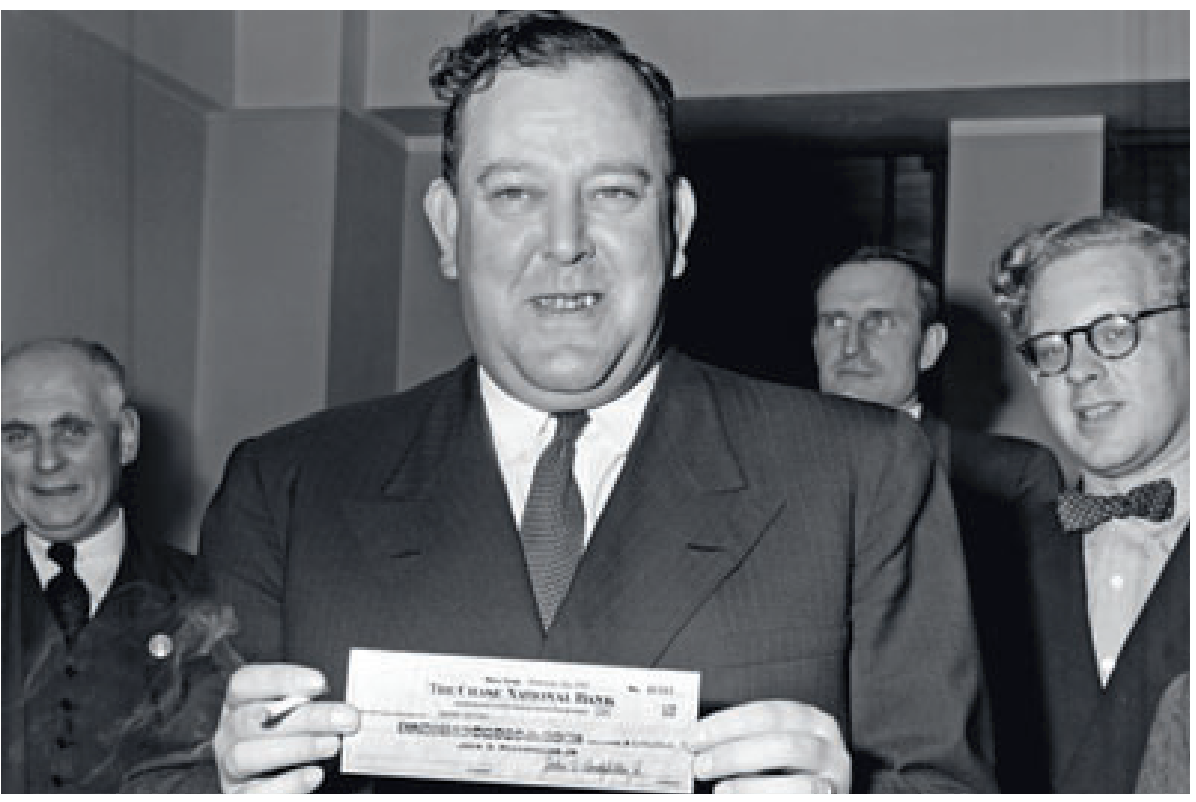

Andre tider: Trygve Lie, første generalsekretæren i FN, tek imot ein gåvesjekk fra Rockefeller til FN-bygningen. Røyken har han i handa. Foto UN Photo/x

Årleg døyr det på verdsbasis 5,4 millionar menneske av tobakksbruk. Dersom dette held fram, ventar ein at over åtte millionar vil døy av tobakksbruk innan 2030. Av desse dødsfalla vil $80 \%$ vere i utviklingslanda, der bruken av tobakk er aukande (1). Dette omtalast som ein global epidemi og tydeleggjer kor viktig det er med felles innsats for å eliminere tobakksbruken.

Kvart år held FN såkalla høgnivåmøte, som er særs profilerte møte med deltaking på høgt politisk nivå. I haust er temaet ikkjesmittsame sjukdommar (2). Norske styresmakter ønskjer å setje eit særskilt søkjelys på tobakk under dette møtet, og den norske FN-delegasjonen i New York har allereie starta arbeidet. På Verdas røykfrie dag 31. mai 2011 vil Noreg i samarbeid med Uruguay og Thailand halde eit arrangement i FN for å feire rammekonvensjonen om førebygging av tobakksskadar frå Verdas helseorganisasjon (WHO). Heile 172 land har forplikta seg til rammekonvensjonen, som vart vedteke i 2003, med verknad frå 2005 . WHO uttalar at den er det sterkaste verkemidlet for tobakkskontroll ein har. Men det er ikkje same sak å vere part i konvensjonen som å gjennomføre forpliktingane i nasjonal rett. Her står det mykje att før ord kan bli omsett til konkret handling.

\section{Tobakksindustrien saksøkjer Noreg og Uruguay}

Bakgrunnen for at mellom anna Noreg og Uruguay går saman om arrangementet
31. mai er at dei er saksøkte av den store tobakksprodusenten Philip Morris. Produsenten saksøkjer Noreg grunna forbodet mot synleg tobakk i norske butikkar. Dette er eit tiltak som òg vart innført på Island i 2001. Uruguay er saksøkt fordi dei har vedteke at $80 \%$ av utsida på tobakkspakka skal vere informasjon/bilete om skadeverknadane av tobakk og at det på dei resterande $20 \%$ ikkje skal brukast fargar/fargekoding. Philip Morris meiner lovendringane i Uruguay er i strid med ei bilateral investeringsavtale mellom Uruguay og Sveits. Søksmåla synar heilt klårt den utfordrande situasjonen mange land står i når det gjeld å innføre restriktivt lovverk i kampen mot tobakk.

Både Uruguay og Thailand har vore særs progressive i kampen mot tobakken og har lovgjeving med utgangspunkt i rammekonvensjonen. I Thailand er det mellom anna oppretta eit eige helsefond som mottek midlar frå tobakksavgifter.

\section{Kampen om midlane}

Noreg er eit av dei medlemslanda i FN som meiner at tobakksrelaterte avgifter er eit unytta potensial i mange land både som førebyggingstiltak og inntektskjelde (3). Men fleire av medlemslanda held fast på at tobakk er eit lovleg produkt på line med andre og difor ikkje må ha særskilte avgifter. Mange land har inntekter frå internasjonale tobakksverksemder som har produksjon der. Slike avgifter utgjer enorme inntektskjelder, i 2009 hadde Noreg 7,4 milliardar kroner i inntekt berre på tobakksrelaterte avgifter (Fredrik Robsahm, personleg melding).

Trass i at ei rekkje av medlemslanda ikkje ynskjer å setje i verk ein slik avgiftspolitikk, vil dei under det komande høgnivåmøtet be om finansiering av helsevesenet $i$ sine respektive land grunna auken i ikkje-smittsame sjukdommar. Men det er langt dyrare å diagnostisere, behandle og førebygge livsstilssjukdommar enn å behandle dei infeksjonssjukdommane som rammar hardast i dei fattigaste landa, til dømes malaria og diaré. Den norske ambassadøren til FN, Morten Wetland, er difor uroa over at vektlegginga av ikkjesmittsame sjukdommar vil føre til dreiing i bistandsmidlane frå dei fattigaste til dei mindre fattige landa (Morten Wetland, personleg melding).

\section{Vegen vidare...}

Ei rekkje land ventar at eit av utfalla frå møtet skal vere auka økonomisk støtte. Interessene er vidare fleirfaldige - på den eine sida lækjarane som bed om meir førebygging, diagnostikk og behandling, og på den andre sida store industriaktørar med fleire økonomiske interesser. Dette vil by på ei rekkje utfordringar og moglege diskusjonar i tida framover.

Richard André Våge

richard.andre.vage@mfa.no

Richard André Våge (f. 1986) har gått forskerlinjen og er cand.med. og stud.jur. For tiden er han praktikant ved den norske FN-delegasjonen.

Ingen oppgitte interessekonflikter.

\section{Litteratur}

1. World Health Organization Report on the Global Tobacco Epidemic, 2008: the MPOWER package. WHO: Genève: 2008

2. Scope, modalities, format and organization of the high-level meeting of the General Assembly on the prevention and control of non-communicable diseases (A/RES/65/238) www.un.org/ga/search/ view_doc.asp?symbol=A/65/L.50\&referer=http:// www.un.org/en/ga/president/65/issues/ ncdiseases.shtml\&Lang=E

3. Prabhat J. Avoidable global cancer deaths and total deaths from smoking. Nat Rev Cancer 2009; 9: 655-64.

Mottatt 27.4. 2011, første revisjon innsendt 10.5 2011, godkjent 12.5. 2011. Medisinsk redaktør Anne Kveim Lie. 